\title{
Characteristics of nonpoint source pollution load from crop farming in the context of livelihood diversification
}

\author{
SHAO Jing'an ${ }^{1,2}$, HUANG Zhilin ${ }^{3}$, DENG Hua ${ }^{4}$ \\ 1. College of Geography and Tourism, Chongqing Normal University, Chongqing 400047, China; \\ 2. Key Laboratory of Surface Process and Environment Remote Sensing in the Three Gorges Reservoir Area, \\ Chongqing 400047, China; \\ 3. Institute of Forest Ecological Environment and Protection, CAF, Beijing 100091, China; \\ 4. Chongqing Youth Vocational \& Technical College, Chongqing 400712, China
}

\begin{abstract}
Based on objective data collected from interviews in typical villages of the Three Gorges Reservoir Area, the present study devised three livelihood scenarios related to rural transformation development: agriculturally dominant livelihood, multiple-type livelihood and non-agriculturally dominant livelihood. Moreover, the present study reports the trend characteristics of nonpoint source pollution load of crop farming in relation to the transformation of dominant livelihood types, and discussed the primary factors which affect livelihood type transformations. Results indicated the following: (1) The current farmland pattern shows a trend of diversification as self-cultivation, cropland transfer and fallow in the sample region. Dynamic characteristics of cultivated land present a special feature that is more "transfer-into" than "transfer-out". Various scales of planting are represented among the various households, according to the following decreasing order: half-labor household > non-labor household > adequate labor household. (2) The highest pollution loading produced by crop farming occurs in half-labor households while the lowest occurs in non-labor households. With increasing labor, the pollution load per unit area tends to first increase and then decrease within families with enough labor. (3) As the type of livelihood transitions from agriculturally dominant to non-agriculturally dominant, the maximum reduction of total pollution loading produced by the agricultural industry can reach $72.01 \%$. Compared to agriculturally dominant livelihoods, multiple-type livelihoods produce a pollution load reduction yield of $19.61 \%-29.85 \%$, and non-agriculturally dominant livelihoods reduce the pollution load yield by $35.20 \%-72.01 \%$. However, the rate of reduction of total nitrogen is not the same as total phosphorus. (4) The non-agricultural characteristics of labor allocation and income promote the transformation from dominant livelihood types to non-agricultural livelihoods, while potential revenue conversion follows a similar trend. In addition, different household types do not display identical conversion rates, according to the following decreasing order: enough labor household >
\end{abstract}

Received: 2017-03-11 Accepted: 2017-05-05

Foundation: Chongqing University Innovation Team for 2016, No.CXTDX201601017; Chongqing Research Program of Basic Research and Frontier Technology, No.cstc2017jcyjBX0024

Author: Shao Jing'an (1976-), Professor, specialized in regional environment evolution and climate responses. E-mail: shao_ja2003@sohu.com 
half-labor household > non-labor household. (5) During rapid urbanization and the building of new industrial systems, the livelihood types of rural households have been further transformed to off-farm household types in the mountainous region; this process will lead to the further reduction of pollution load generated by planting and agriculture. Hence, significant decreases in the planting pollution load necessitate the development of control measures to enhance transformations from agricultural to off-farm livelihoods.

Keywords: livelihood; crop farming; nonpoint source pollution; evolution; Three Gorges Reservoir Area

\section{Introduction}

Environmental impact of crop farming (CF) becomes increasingly prominent in rural China. An investigation into this issue can help relieve the environmental pressure faced by rural areas. As was pointed out at the Central Rural Work Conference in 2014 held by China's Communist Party Central Committee and State Council, the ecological environment has given a warning to agricultural development and extensive farming, which is characterized by high yield, high quality and high economic efficiency, had exerted considerable negative impact on rural environment (Liang et al., 2010). In view of current stage of agricultural and rural development in China, maximization of households' welfare and income, driven by policy orientation as well as development and transformation of rural economy, plays a critical role in resource allocation and household livelihood strategies in rural areas (Rozelle and Boisvert, 1995; Liu, 2007). It leads to a shift of main livelihood to non-agricultural activities, diversified farm operators (Shui, 2013) and growth of precision (Ganesh et al., 2012) and multi-functional agriculture (Walford, 2005). However, nonpoint source (NPS) pollution, considered one of the main factors affecting rural environment, is an unavoidable and sensitive issue that rural China must face at present and in the future (Yang et al., 2013). Related studies suggest that pollution load from agricultural production is one of the main nonpoint sources of pollution ( $\mathrm{Li}$ et al., 2010) and the application of fertilizers has a great impact on water quality in local water environment (Zhang et al., 2012). Some scholars argue that the influences of fertilizer application vary significantly between operating entities (Zhong et al., 2014) and peasant households' attitudes towards inputs to farmland greatly affect their decisions on fertilizer use (Gong et al., 2008) and their management behavior has an important influence on NPS pollution in rural areas (Feng et al., 2005; Hou et al., 2012).

It is no doubt true that the growing wages paid for migrant workers boosts mass migration of labor from rural areas (Sharma et al., 2006; Zhang et al., 2009; Zhao et al., 2013; Long et al., 2014). In mountainous rural areas, agricultural production is at a marked comparative disadvantage due to topographical restrictions and people's livelihoods depend less on land. Therefore, labor is migrating out of these areas at impressively rapid rates ( $\mathrm{Li}$ and $\mathrm{Ma}, 2014$ ). This survey finds that migrant workers from mountainous countryside are mostly aged below 50 and their rational judgments and decisions on livelihood are largely aimed at maximizing income. Most of the left-behind laborers are aged between 50 and 65. They are primarily engaged in subsistence agriculture and exhibit low degree of participation in the market. The left-behind peasants older than 65 only mostly rely on vegetable gardens or subsistence agriculture for their livelihood, which are characterized by limited land sizes and intensive land use. The migrant rural workers were generally employed in non-agricultural 
sectors, while the left-behind ones are primarily engaged in both agriculture and supplementary sidelines concurrently or merely agriculture. Rural households with different livelihood strategies vary widely in environmental awareness (Zhao, 2012), attitude towards land, and inputs to agricultural production (Ouyang et al., 2004; Luo et al., 2013). This variability has an inevitable effect on the level of NPS pollution in rural areas. Therefore, it is very necessary to investigate how the nonpoint sources of pollution caused by CF vary as household livelihoods change and to implement control of pollution from nonpoint sources at the household level.

The variability in peasant households' responses to livelihood changes and in their attitudes towards inputs to farmland ultimately causes variations in the levels of NPS pollution from CF in rural areas. In view of this, this study investigated the pattern of variation in NPS pollution produced by CF during the evolution of peasant households' main livelihoods and the resulting responses of various household types under the framework of income maximization. It is suggested that adaptive control policies should be formulated based on a weighing of diversified livelihood options and inputs to farmland, in order to provide guidance to various operators, such as peasant households, cooperatives, and enterprises, on proper agricultural inputs and to prevent NPS pollution in rural areas through control of sources.

\section{Materials and methods}

\subsection{Overview of the sample areas}

The sample areas include Futian and Longxi towns in Wushan County as well as the Baima and Changba Towns in Wulong County. Both counties are typical mountainous areas within the Three Gorges Reservoir Area. Wushan County is located within the Northeast Chongqing Ecological Conservation and Development Zone and next to the Daning River, while Wulong County is located within the Southeast Chongqing Ecological Protection and Development Zone and close to the Wujiang River (Figure 1). Both rivers are main tributaries of the Yangtze River. Overall, the sample area in Wushan County slopes steeply towards the northeast and its terrain is primarily composed of middle and low mountains. It has a subtropical humid monsoon climate that varies significantly across this area, with an annual precipitation of $1041 \mathrm{~mm}$ and annual mean temperature of $18.4^{\circ} \mathrm{C}$. Futian Town is about 60 $\mathrm{km}$ from the county seat. Local staple crops are corn, rice and sweet potato and double cropping is practiced there. Located $10.3 \mathrm{~km}$ from the county seat, Longxi Town is largely forested and mainly produces corn, sweet potato and sesame. About $46.49 \%$ of local labor has migrated to urban areas in search of non-agricultural jobs. The sample area in Wulong Town gently slopes from southeast to northwest and its terrain is characterized by flat river valleys, deep hills and low mountains. It also has a subtropical humid monsoon climate with an annual precipitation of around $1100 \mathrm{~mm}$ and a frost-free season of 260 days. Changba Town is $38 \mathrm{~km}$ away from the county seat and accessible by National Highway 319 . It has a relatively solid foundation for agricultural production with rice, corn and rapeseed being local staple crops. Around $24 \mathrm{~km}$ from the county seat, Baima Town has relatively developed infrastructure such as transport and water conservation facilities and produces corn, rice, flue-cured tobacco, rapeseed, etc. 


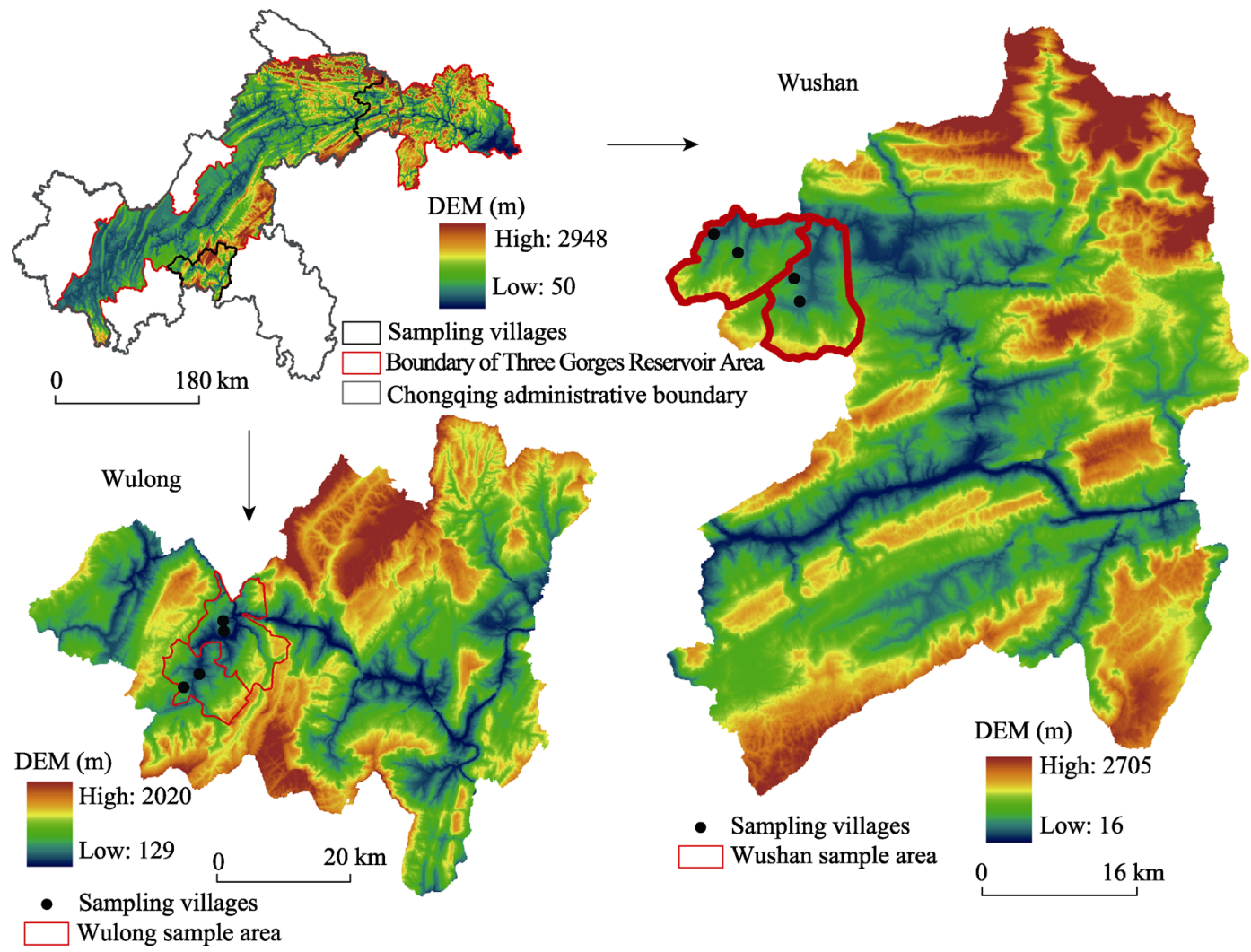

Figure 1 Location of the study site and distribution of the sampling villages

This study focused on eight typical villages, including Lianhua, Shuangtang, Shuanghe, and Laoya in Wushan County as well as Eguan, Qianjin, Dongsheng, and Chepan in Wulong County, and involved 2814 people. Local contracted farmland per capita over the research period was $11.21 \times 10^{-2} \mathrm{hm}^{2}, 4.40 \times 10^{-2} \mathrm{hm}^{2}$ of which was left uncultivated. Annual income from land per unit area was between 819.67 and 1464.29 yuan and the subsidies for each farmer ranged from 593.96 to 1775.10 yuan. Annual income per capita among the migrant workers from these areas was 20,101.02 yuan, and the left-behind farmers with sidelines earned 5801.54 to $14,686.07$ yuan a year. Occupations of labor force in the sample villages varied significantly between age groups (Table 1).

Table 1 The situations of labor resource allocation among different ages (person)

\begin{tabular}{|c|c|c|c|c|c|c|}
\hline \multirow{2}{*}{$\begin{array}{l}\text { Age group } \\
\text { (years old) }\end{array}$} & \multicolumn{6}{|c|}{ Labor resource allocation } \\
\hline & $\begin{array}{l}\text { Migrant } \\
\text { workers }\end{array}$ & $\begin{array}{l}\text { Non-working } \\
\text { people }\end{array}$ & $\begin{array}{l}\text { Agricultural } \\
\text { workers }\end{array}$ & $\begin{array}{l}\text { Main migrant } \\
\text { workers }\end{array}$ & $\begin{array}{l}\text { Main agricul- } \\
\text { tural workers }\end{array}$ & Total \\
\hline$<16$ & 3 & 536 & 7 & - & - & 546 \\
\hline $16-50$ & 607 & 168 & 414 & 198 & 15 & 1402 \\
\hline $50-65$ & 25 & 23 & 427 & 45 & 9 & 529 \\
\hline$>65$ & 1 & 77 & 253 & 4 & 2 & 337 \\
\hline Total & 636 & 804 & 1101 & 247 & 26 & 2814 \\
\hline
\end{tabular}

\subsection{Data sources}

Survey data: This study mainly used survey data acquired by means of participatory rural 
appraisal (PRA), which was carried out over about 60 days in July and August 2012. Peasant households randomly sampled from the villages were asked to fill in a questionnaire and return it. A total of 691 valid copies were collected, with 98, 92, 98, 86, 77, 81, 80, and 79 copies from Laoya, Shuanghe, Lianhua, Shuangtang, Eguan, Qianjin, Chepan, and Dongsheng, respectively. This survey focused on the livelihood assets (including human assets, natural assets, physical assets, etc.) and livelihood strategies of the households. Additionally, this study also used data from a questionnaire survey conducted in some districts (counties) of Chongqing within the Three Gorges Reservoir Area between June and October 2013. A total of 758 copies of the questionnaires were submitted to households in 46 villages, 23 townships (towns) and 752 valid copies were collected. This survey examined the status quo of the households, structure of CF, land area under cultivation, fertilizer application, management mode, structure of husbandry, and rural life.

Spatial data: Spatial data, such as county-level digital elevation model (DEM) data as well as data about the Yangtze River system, the administrative divisions of the Three Gorges Reservoir Area, and the administrative boundary of Chongqing were downloaded from the Geospatial Data Cloud website (http://www.gscloud.cn/). The 1:10,000 topographic maps of the village, land use maps, village-level road map, settlement distribution maps, and drainage patterns were provided by land offices at the township (town) level or bureaus of land and resources at the county level. The spatial distribution of the survey points in the sample villages was obtained by inserting their GPS coordinates into the above-mentioned maps.

\subsection{Data processing}

(1) Classification of peasant household types (HH type)

The household samples in this study were classified into three types based on household composition: households with able-bodied laborers (HH type 1), households with semi-able-bodied laborers (HH type 2), and households with no laborer (HH type 3). A household with able-bodied laborers refers to a household that has able-bodied members (aged between 16 and 50) engaged in production. A household only with semi-able-bodied laborers has no able-bodied adult but has semi-able-bodied members (aged between 50 and 65 ) engaged in production. In a household with no laborer, all adults are older than 65 and engaged in certain agricultural production.

(2) Livelihood types in different scenarios (LH type)

The peasant households' livelihoods were classified into three types according to their attitude towards land, dominant livelihood strategy, dependence of livelihood on family-contracted farmland, and inclination to adopt a diversified livelihood strategy (see more details in Table 2).

Table 2 The scenario classification of different farmer livelihood types

\begin{tabular}{cccccc}
\hline $\begin{array}{c}\text { Farmer livelihood } \\
\text { scenario types }\end{array}$ & $\begin{array}{c}\text { Major livelihood } \\
\text { assets }\end{array}$ & $\begin{array}{c}\text { Leading liveli- } \\
\text { hood strategy }\end{array}$ & $\begin{array}{c}\text { Land dependence } \\
\text { degree }\end{array}$ & $\begin{array}{c}\text { Land transfer } \\
\text { intensity }\end{array}$ & $\begin{array}{c}\text { Main farm household } \\
\text { income }\end{array}$ \\
\hline LH type 1 & Natural assets & Agriculture & High & Low & Agricultural products \\
LH type 2 & $\begin{array}{c}\text { Natural assets and } \\
\text { human capital }\end{array}$ & $\begin{array}{c}\text { Agriculture and } \\
\text { sidelines }\end{array}$ & Relatively high & Relatively strong & $\begin{array}{c}\text { Non-farm income and } \\
\text { agricultural products }\end{array}$ \\
LH type 3 & $\begin{array}{c}\text { Human capital and } \\
\text { social assets }\end{array}$ & No-agriculture & Low & Strong & Non-farm income \\
\hline
\end{tabular}

Note: The meaning of farmer livelihood types is explained in the following page. 
LH type 1: Livelihood dominated by agriculture. In this scenario type, the peasant households earned their livelihood primarily from land resources, especially the family-contracted farmland which provided the fundamental income to support a family's daily life. They usually carried out single types of activities for a means of living and sought to maximize farm output per unit land area in pursuit of maximum income from farmland. Hence, farmers were not engaged in other non-agricultural jobs and their land was retained or transferred on a small scale. Land resources were fully developed and utilized and no land was left uncultivated.

LH type 2: Livelihood dominated by sidelines. In this scenario type, the peasant households' livelihood partly relied on the limited land resources and the labor could flow freely between industries. The able-bodied workers regarded agricultural production as the worst choice for their livelihood. Land transfer became increasingly active. However, as there was a lack of established guarantee mechanism to protect peasants' rights and interests during land transfer, various farm operators had a wait-and-see attitude towards farmland. As a result, part of the land was transferred, while the rest was farmed or left uncultivated. In this scenario type, the bulk of the able-bodied laborers chose better-paid occupations and attached little importance to land. Therefore, their land was most likely to be transferred. Only a small part of the semi-able-bodied laborers worked as migrant workers, while the rest earned their livelihood from both farming and supplementary sidelines. The attitudes of the farmers with sidelines towards farmland depended on their income from farmland. Land transfer was more likely to occur if it could bring greater economic benefits; otherwise, the peasants were more likely to retain their land. The attitudes of those aged over 65 towards land rested with their family status and their earnings after land transfer. These people generally supported compensatory land transfer.

LH type 3: Livelihood dominated by non-agricultural activities. In this scenario type, land transfer took place in a more mature manner and was protected by related support mechanisms. Peasants had not to worry about their livelihood after transferring their land. Both operating entities and households could obtain expected profits from land. Additionally, the companies and other high-level operating entities that took over land from individual households were able to make best use of land resources, significantly improving land use efficiency.

As the households changed their principal livelihood, the operating entities of farmland developed into high-level operators. In this scenario type of agriculture-based livelihood, farmland was operated by contracted farmers and big families engaged in farming. In the second type described above, the operating entities included contracted farmers, big families engaged in farming, cooperatives and companies, and the farmland was under cultivation, transferred, or left uncultivated. In the third type, cooperatives or companies replaced individual households to manage agricultural production in an organized manner.

(3) Calculation of income/welfare of households with different livelihood strategies

As a result of economic transformation and growth in rural areas, the sources of households' livelihood tend to be diversified. The survey found that the incomes of the households mainly came from non-agricultural activities, agricultural production, sidelines, contracted farmland, as well as assistance from the government, relatives and friends. According to the rational peasant hypothesis and the maximum objective decision function, household inc- 
ome can be expressed as follows:

$$
\text { Income }_{j}=\sum\left(O F+F_{m}+C B+L+A F\right)
$$

where Income $_{j}$ represents the total income of a type $j$ household; $O F$ is the income from non-agricultural sources; $F_{m}$ is the income from agriculture; $C B$ is the income from sidelines; $L$ is the income from farmland; and $A F$ is the income from assistance (e.g. government subsidies and assistance offered by friends and relatives). The expressions for the incomes from different sources are as follows: $O F=\sum N_{W} \cdot O F_{W}, F_{m}=\sum_{m=1}^{k} q_{m} \cdot p_{m} \cdot A_{m}, C B=\sum N_{J}$. $C B_{J}, L=\sum_{L=1}^{k} A_{L} \cdot L a_{L}$, and $A F=\sum_{f=1}^{k} A F_{f}$, where $N_{w}$ is the number of migrant workers; $O F_{W}$ is the average annual income from non-agricultural sources; $q_{m}$ is the unit price of the $m$ th crop (animal) product; $p_{m}$ is the yield of the $m$ th crop (or animal) product per unit land area; $A_{m}$ is the area of land used to produce the $m$ th crop (animal) product; $N_{j}$ is the number of peasants with sidelines; $C B_{J}$ is the average annual income from sidelines; $A_{L}$ is the area of land that brings the $L$ th income; $L a_{L}$ is the $L$ th income from farmland per unit area; and $A F_{f}$ is the income from the $f$ th assistance.

(4) Correction for coefficient of river pollutant input for different household types

Pollutants generated by CF in different spatial units are carried by surface runoff to receiving water bodies. This process is mainly controlled by surface roughness and the component of gravity parallel to surface slope (Long et al., 2013). Besides, the distance between a pollutant-producing unit and a receiving water body also affects the likelihood and rate of pollutant input into the receiving water body. The shorter the distance, the less varied the topography and land use types in the area between the pollutant source and the receiving water body. Thus the pollutants are more likely to enter the receiving water body rather than be intercepted or absorbed by land. Therefore, the coefficient of river pollutant input increases with increasing component of gravity along the surface slope and decreasing distance from a pollutant source to a receiving water body. Since topographical index can reflect the component of gravity parallel to the slope of a spatial unit (Beven and Kirkby, 1979), it was used to correct the distance between a spatial unit and a receiving water body as follows:

$$
D_{i}=d_{i} \cdot \ln \frac{\alpha_{i}}{\tan \beta_{i}}
$$

where $D_{i}$ and $d_{i}$ are the corrected distance and Euclidean distance between spatial unit $i$ and the receiving water body, respectively; $\ln \frac{\alpha_{i}}{\tan \beta_{i}}$ is topographic index; $\alpha_{i}$ is the catchment area per unit contour length within unit $i\left(\mathrm{~m}^{2}\right)$; and $\tan \beta_{i}$ is the slope of unit $i\left(^{\circ}\right)$.

$$
\lambda_{n}=\bar{\lambda} \cdot \frac{\bar{D}}{D_{n}}
$$

where $\lambda_{n}$ is the coefficient of river pollutant input from sample point $n ; \bar{\lambda}$ is the average coefficient of river pollutant input; $\bar{D}$ is the average distance between farmland and the receiving water body; and $D_{n}$ is the distance from sample point $n$ to the receiving water body. The value of $\bar{\lambda}$ can be obtained from the results of research conducted by the agro-enviro- 
nmental monitoring stations in Chongqing and Hubei (Chen et al., 2008; Zhong et al., 2015). The coefficients of TN (total nitrogen) and TP (total phosphorus) inputs were determined to be $\lambda_{T N}=0.1007$ and $\lambda_{T P}=0.0599$, respectively. Table 3 lists the coefficients of river pollutant input from the survey points in the study areas.

Table 3 The value range of river load ratio of pollutants resulted by planting of different farmers

\begin{tabular}{ccccc}
\hline Sampling site & TN value range & TN mean value & TP value range & TP mean value \\
\hline Wushan & $0.0675-0.3902$ & 0.1221 & $0.0401-0.2321$ & 0.0726 \\
Wulong & $0.0485-0.4906$ & 0.1006 & $0.0289-0.2919$ & 0.0598 \\
\hline
\end{tabular}

(5) Calculation of NPS pollution produced by CF in various scenario types

As a growing portion of rural labor entered non-agricultural sectors, the dominant livelihood of the peasant households in the study areas changed from agriculture to sidelines and then to non-agricultural work. The NPS pollution load from CF can be calculated using the following equation:

$$
P L_{j}=\sum_{n=1}^{m} P L_{n}
$$

where $P L_{j}$ is the total pollution load resulting from CF conducted by household with type $j$ livelihood; $P L_{n}$ is the total pollution load from $\mathrm{CF}$ at sample point $n$, given by

$$
P L_{n}=\lambda_{n} \cdot \sum_{i=1}^{n} A_{i} \cdot F_{i}
$$

where $\lambda_{n}$ is the corrected coefficient of river pollutant input from point $n, A_{i}$ is the area of land used for type $i \mathrm{CF}$ at point $n$, and $F_{i}$ is the input to farmland for type $i$ crop farming. Their values can be determined based on findings of previous research (Zhong et al., 2014).

\section{Results and analysis}

\subsection{Farmland use and pollution load from CF by different household types}

(1) Farmland use by different types of rural households

In the study areas, part of the farmland was cultivated by original farmers, while the rest was transferred or left uncultivated. The scale of farmland operation varied significantly between different types of rural households. Table 4 reveals that the total area of farmland newly acquired by the households was smaller than the sum of the areas of uncultivated land and land transferred by the households. This indicates that the mountainous areas studied had sufficient available farmland due to the increased off-farm employment among local labor, providing relatively rich opportunities for the households to acquire high- quality farmland. This also implies that some households may have been involved in transferring farmland, leaving some farmland uncultivated, and acquiring new farmland simultaneously. The transfer of farmland, driven by the pursuit of maximum efficiency of farming, can greatly help optimal allocation and reallocation of arable land in mountainous areas.

The average land area under cultivation per capita among HH type 2 households, i.e. households with semi-able-bodied laborers, was $11.02 \times 10^{-2} \mathrm{hm}^{2}$, greater than the $8.66 \times 10^{-2} \mathrm{hm}^{2}$ 
Table 4 Farmland use of different household livelihood types and nonpoint source pollution load resulted by planting

\begin{tabular}{ccccccccccc}
\hline $\begin{array}{c}\text { Household } \\
\text { type }\end{array}$ & $\begin{array}{c}\text { Labors per } \\
\text { household } \\
\text { (person) }\end{array}$ & $\begin{array}{c}\text { Farmland } \\
\text { area under } \\
\text { actual culti- } \\
\text { vation* }\end{array}$ & $\begin{array}{c}\text { Family- } \\
\text { contracted } \\
\text { farmland } \\
\text { area* }\end{array}$ & $\begin{array}{c}\text { Transfer- } \\
\text { ring into } \\
\text { farmland } \\
\text { area* }\end{array}$ & $\begin{array}{c}\text { Transfer- } \\
\text { ring out } \\
\text { farmland } \\
\text { area } *\end{array}$ & $\begin{array}{c}\text { Return- } \\
\text { ing } \\
\text { farmland } \\
\text { area* }\end{array}$ & $\begin{array}{c}\text { Aban- } \\
\text { doned } \\
\text { farmland } \\
\text { area* }\end{array}$ & $\begin{array}{c}\text { TN** } \\
\text { TP** }\end{array}$ & $\begin{array}{c}\text { Total } \\
\text { load } \\
* *\end{array}$ \\
\hline HH type 1 & 1 & 9.02 & 17.93 & 1.11 & 2.16 & 6.69 & 1.17 & 35.70 & 18.02 & 53.72 \\
& 2 & 6.44 & 9.77 & 1.18 & 0.73 & 3.05 & 0.72 & 34.15 & 19.30 & 53.45 \\
& 4 & 7.00 & 9.22 & 1.67 & 0.96 & 2.22 & 0.70 & 38.45 & 20.19 & 58.64 \\
\hline HH type 2 & 1 & 4.72 & 7.96 & 1.18 & 0.85 & 3.00 & 0.55 & 35.69 & 21.70 & 57.39 \\
\hline HH type 3 & 2 & 11.34 & 22.55 & 1.81 & 1.57 & 9.82 & 1.64 & 37.53 & 23.40 & 60.92 \\
\hline Mean value & - & 8.79 & 8.38 & 0.38 & 0.13 & 3.00 & 0.84 & 28.77 & 19.09 & 47.86 \\
\hline
\end{tabular}

Note: * The unit is $10^{-2} \cdot \mathrm{hm}^{2} /$ person, and $* *$ the unit is $\mathrm{kg} \cdot \mathrm{hm}^{-2}$.

among HH type 3 households and $6.45 \times 10^{-2} \mathrm{hm}^{2}$ among $\mathrm{HH}$ type 1 households. Despite their sufficient numbers of laborers, HH type 2 households were deprived of the opportunity to choose better livelihood strategies due to limitations such as oldness, low educational levels and physical conditions. Therefore, they carried out farming on a larger scale and were more dependent on land than the other two types. Due to a shortage of manpower and "fixation on land", HH type 3 households which had no working-age adult normally earned their livelihood from large-scale farming and thus were highly dependent on land for their livelihood. However, with limited physical ability, their family members were often engaged in agricultural production near their homes. The HH type 1 households exhibited the smallest average land area under cultivation per capita, because workers in these households were shifting away from agriculture in large numbers for the comparative disadvantage of agricultural production. Additionally, for an $\mathrm{HH}$ type 1 household, an increase in its laborer number further diminished its land area under cultivation per capita, indicating that rural households with more laborers were less dependent on farmland.

(2) Pollution load from CF by different household types

The average pollution load from CF per unit land area was $58.50 \mathrm{~kg} \cdot \mathrm{hm}^{-2}$ among $\mathrm{HH}$ type 2 households, compared with 54.21 $\mathrm{kg} \cdot \mathrm{hm}^{-2}$ among $\mathrm{HH}$ type 1 households and $47.20 \mathrm{~kg} \cdot \mathrm{hm}^{-2}$ among $\mathrm{HH}$ type 3 households. The TN and TP from farmland per unit area followed the same pattern (Figure 2). Moreover, as the number of laborers in an HH type 1 household increased, the total pollution load, $\mathrm{TN}$, and TP from CF increased and then decreased (Table 4). The increased laborer numbers ensured adequate labor input to ag-

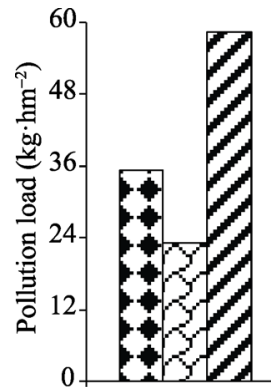

HH type 1
๑N $\square \mathrm{TP} \square$ Total load

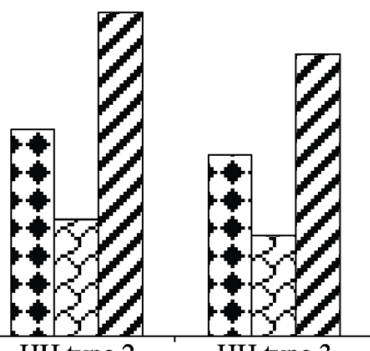

HH type 2

Figure 2 Pollution load per unit area of different farmer livelihood types

Note: The means of type 1, type 2 and type 3 are shown in the part of classification of peasant households. 
ricultural production. The heavy use of fertilizers driven by the pursuit of maximum profit increased the pollution load from CF. However, as the number of laborers increased to a certain level, comparatively low incomes from farming inevitably forced the households to shift away from agriculture to non-agricultural sectors. The massive labor shift resulted in declines in the number and work ability of laborers available for agricultural production. This substantially restricted fertilizer inputs, thereby reducing the CF-related pollution load.

\subsection{Variation in pollution load from CF with livelihood changes}

(1) Characteristics of variation in pollution load from $\mathrm{CF}$

The pollution load from CF decreased as the rural households changed their main livelihood. This trend was especially evident in TN. Table 5 shows that the livelihood transition from agricultural to non-agricultural activities resulted in a maximum reduction of $12.40 \mathrm{t}$, or $72.01 \%$, in the pollution load from CF. However, TN and TP decreased at different rates: $\mathrm{TN}$ by $9.62 \mathrm{t}(83.00 \%)$ and $\mathrm{TP}$ by $3.61 \mathrm{t}(64.12 \%)$. The TN reduction caused by liveli-

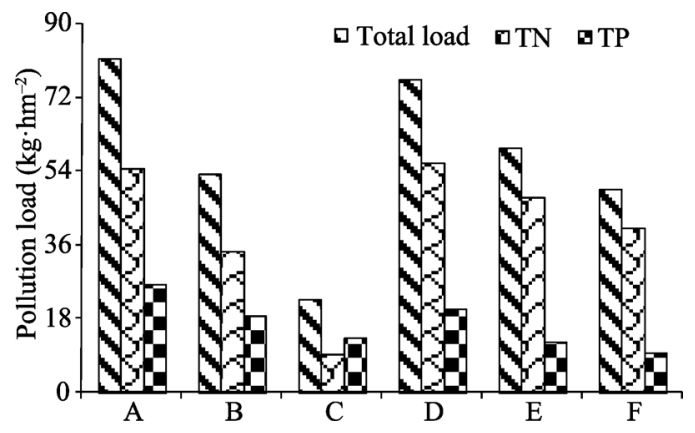

Figure 3 Pollution load per unit area among different main agricultural operating bodies

Note: The meanings of A, B, C, D, E and F are generally scattered households, big planting households, corporation, big breeding households, big planting and breeding households and cooperatives, respectively. hood changes accounted for the highest proportion of the total reduction in the pollution load from $\mathrm{CF}$, at $77.58 \%$. During the livelihood change process, the individual households gradually shifted from agriculture and agricultural management tended to be more advanced and more specialized ( $\mathrm{Xu}$ et al., 2004). Moreover, different operators exhibited very different attitudes towards land and fertilizer application habits (and rates) (Zhong et al., 2014). This contributed to the significant variation in the pollution load from $\mathrm{CF}$ per unit land area among different operators, as illustrated in Figure 3.

Table 5 Nonpoint source pollution load resulted by planting among different farmer livelihood types

\begin{tabular}{clcc}
\hline Farmer livelihood types & Total load $(\mathrm{t})$ & $\mathrm{TN}(\mathrm{t})$ & TP $(\mathrm{t})$ \\
\hline LH type 1 & $17.22-16.22$ & $11.59-11.88$ & $5.63-4.33$ \\
LH type 2 & $13.04-12.08$ & $9.45-8.76$ & $3.58-3.33$ \\
LH type 3 & $10.51-4.82$ & $8.49-1.97$ & $2.02-2.85$ \\
\hline
\end{tabular}

The pollution load from CF varied significantly between stages of livelihood changes. In LH type 1 where agriculture was the main livelihood of the households, contracted farmers acted as the independent operators. In order to maximize output per unit land area, they applied fertilizers to farmland in large quantities. The resulting total pollution loads were relatively high, ranging from 17.22 to $16.22 \mathrm{t}$ (TN: $11.59-11.88 \mathrm{t}$; TP: $5.63-4.33 \mathrm{t}$ ). In LH type 2 where the households' livelihood was dominated by sidelines, the peasants became more involved in the market and gradually entered the secondary and tertiary sectors in search of comparative benefits. Meanwhile, the semi-able-bodied peasants took a wait-and-see at- 
titude towards farmland. The emerging operating entities were at a stage of transition in the context of economic transformation. The land was independently farmed by contracted farmers or transferred to others or left uncultivated. Compared to LH type 1, the pollution load from CF decreased by 3.18 to 5.14 t, or $19.61 \%$ to $29.85 \%$; TN and TP decreased by 2.14 to $3.12 \mathrm{t}$ and 0.75 to $2.30 \mathrm{t}$, respectively, with their maximum reduction rates exceeding $25.0 \%$. In LH type 3 where the households' livelihood was dominated by non-agricultural activities, the land transfer market was active and the operators had transitioned to higher-level forms. The pollution load from CF significantly dropped to relatively low levels compared to LH type 1. The total pollution load reduced by 5.71 to $12.401 \mathrm{t}$, or $35.20 \%$ to $72.01 \%$. The reductions in $\mathrm{TN}$ and $\mathrm{TP}$ fell within the ranges of 3.10 to $9.91 \mathrm{t}$ and 1.48 to $3.61 \mathrm{t}$, respectively, with their maximum reduction rates exceeding $60.0 \%$.

(2) Response of pollution load from CF to livelihood changes

During the livelihood shift process, the reductions in pollution load from CF varied drastically between household types. As Table 6 shows, the rates of reduction in pollution load from CF ranged from $18.64 \%$ to $28.84 \%$ among HH type 1 households, $15.96 \%$ to $23.12 \%$ among $\mathrm{HH}$ type 2 households, and $21.13 \%$ to $39.47 \%$ among HH type 3 households. The three household types were ranked in descending order of maximum reduction rate as follows: HH type 3 households, HH type 1 households, and HH type 2 households. In terms of absolute amount of pollution reduction, $\mathrm{HH}$ type 1 households ranked the highest while $\mathrm{HH}$ type 3 households ranked the lowest.

Table 6 The evolution characteristics of pollution load produced by planting in different farmer livelihood types, associating with the change of leading livelihood types

\begin{tabular}{ccccc}
\hline Family type & Farmer livelihood type & Total load $(\mathrm{t})$ & TN $(\mathrm{t})$ & TP $(\mathrm{t})$ \\
\hline \multirow{3}{*}{ HH type 1 } & LH type 1 & $14.46-13.63$ & $9.73-9.98$ & $4.73-3.64$ \\
& LH type 2 & $11.09-10.29$ & $8.04-7.45$ & $3.05-2.84$ \\
& LH type 3 & $8.83-4.05$ & $7.13-1.65$ & $1.70-2.39$ \\
\hline \multirow{3}{*}{ HH type 2 } & LH type 1 & $1.99-1.88$ & $1.34-1.38$ & $0.65-0.50$ \\
& LH type 2 & $1.58-1.53$ & $1.10-1.06$ & $0.48-0.47$ \\
& LH type 3 & $1.22-0.56$ & $0.98-0.23$ & $0.23-0.33$ \\
\hline \multirow{2}{*}{ HH type 3 } & LH type 1 & $0.76-0.71$ & $0.51-0.52$ & $0.25-0.19$ \\
& LH type 2 & $0.56-0.46$ & $0.44-0.37$ & $0.11-0.09$ \\
& LH type 3 & $0.46-0.21$ & $0.37-0.09$ & $0.09-0.13$ \\
\hline
\end{tabular}

As the main livelihood changed from agriculture to sidelines, HH type 3 households were most likely to transfer their farmland due to a lack of laborer. Most of the transferred farmland was then cultivated on a moderate scale with less fertilizer use per unit land area, thereby substantially reducing the pollution load from CF. HH type 1 households had adequate manpower or time available for agricultural production besides sidelines. Therefore, the time and intensity of farm work per unit land area were relatively high among them. They applied large amounts of fertilizers for the purpose of maximizing outputs per unit land area, resulting in relatively high pollution loads. In LH type 2, the laborers within $\mathrm{HH}$ type 1 households engaged in sidelines were no longer concentrated in agriculture, reducing their labor inputs (including laborers, work time and intensity) to agricultural production com- 
pared to LH type 1. The additional sideline incomes slightly slowed their pursuit of higher yields, thereby cutting the use of fertilizers to some extent. Therefore, the pollution loads from $\mathrm{CF}$ were lower among $\mathrm{HH}$ type 1 households with sidelines also lower than among $\mathrm{HH}$ type 1 households relying on agriculture. A fraction of the semi-able-bodied laborers were involved in sideline activities in LH type 2. However, agriculture remained the main livelihood for HH type 2 households due to their limited labor resources, just like in LH type 1. In order to meet basic necessities and maximize output per unit land area, they still invested heavily in farmland. Therefore, these households exhibited the lowest rates of pollution load reduction.

As the livelihood shifted from sidelines to non-agricultural activities, the pollution load from CF was reduced from $23.31 \%$ to $63.48 \%$ among type 1 households, $20.26 \%$ to $64.56 \%$ among type 2 households, and 0 to $62.50 \%$ among HH type 3 households. In this scenario, individual households had moved away from agriculture and thus the pollution loads from CF were generally low. The highest reduction rate occurred among type 2 households, indicating that the stock of pollutants produced by $\mathrm{HH}$ type 2 households was greater than those by the other two types of households. This is consistent with the fact that labor allocation optimization accompanying the dominant livelihood changes led to considerable variations in the labor inputs to crop farming and thereby noticeable variability in pollution load reduction.

The analysis above reveals that the reduction in pollution load from CF by HH type 3 households was most sensitive to the livelihood shift from agriculture to sidelines, and that by $\mathrm{HH}$ type 2 households was most sensitive to the shift from sidelines to non-agricultural activities.

\subsection{Driving factors behind household livelihood shifts}

The varying rates of pollution load reduction among the households raised two questions: what were the factors contributing to the variability in the trajectory of dominant livelihood among the households and how strong were these factors' effects? An investigation was necessary to find the answers so as to provide a basis for working out measures to address or reduce pollution load from $\mathrm{CF}$ during the transformation of agriculture.

(1) Off-farm employment impelled the livelihood shifts

There was high non-agricultural employment among the households. As Figure 4 shows, the average laborer number per household in the sample areas was 4.07. Agricultural and migrant workers constituted $39.13 \%$ and $22.60 \%$ of local population, respectively, and only $9.70 \%$ had sidelines. Non-working people made up $30.56 \%$ of the population. The non-agricultural employment was high at $32.30 \%$. Figure 5 demonstrates that the major components of different occupational groups differed greatly. More than $95 \%$ of the migrant workers were able-bodied laborers. Semi-able-bodied laborers and those aged over 65 together accounted for $61.76 \%$ of the peasants that were engaged only in agriculture. Able-bodied workers accounted for $78.02 \%$ of the peasants with sidelines. A significant component $(66.67 \%)$ of the non-working population was under 16 years old. The trend away from agriculture was becoming increasingly marked as a result of the transformation of agriculture, exploitation of peasants' potential for getting non-agricultural jobs and the entry of potential workers into the labor force. 


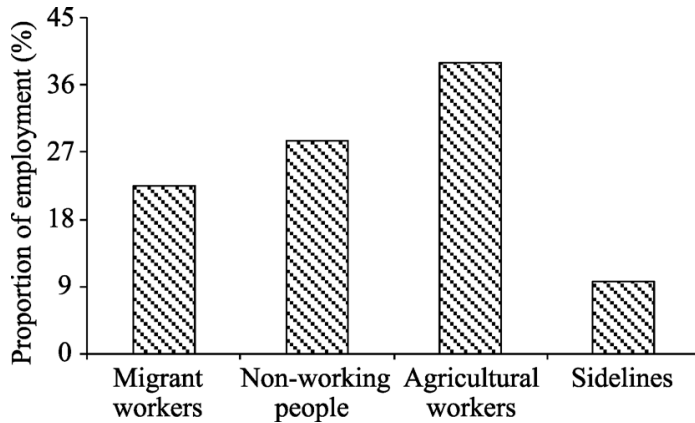

Figure 4 Employment structure of the labor resource

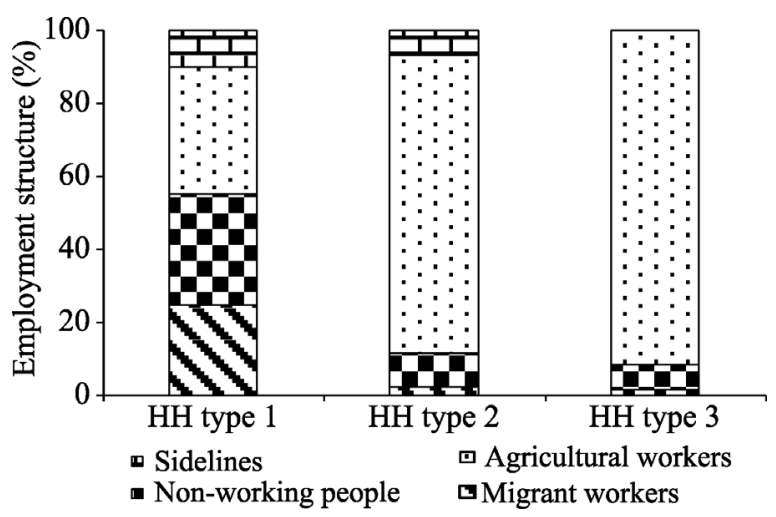

Figure 6 Employment structure of the labor resource in the different farmer livelihood types

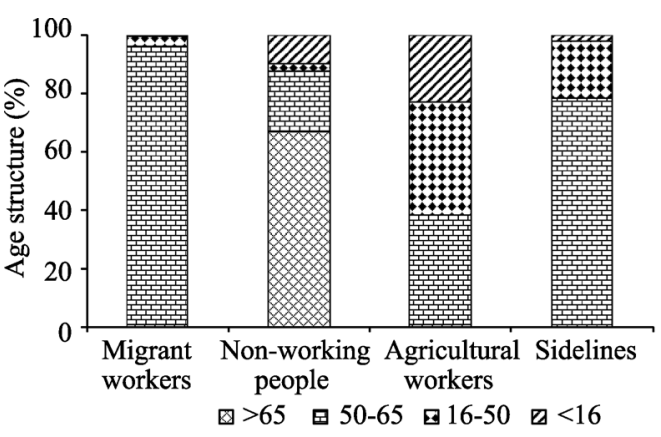

Figure 5 Age structure of labor resource allocation

The proportion of non-agricultural laborers varied between household types. Figure 6 reveals that the average proportion of non-agricultural laborers (migrant workers and members with sidelines) among HH type 1 households reached $34.80 \%$, significantly higher than the $9.34 \%$ among $\mathrm{HH}$ type 2 households and $0.00 \%$ among $\mathrm{HH}$ type 3 households. The average proportions of agricultural workers in family members were high among $\mathrm{HH}$ type 2 and HH type 3 households, both exceeding $80 \%$, implying their high dependence on farmland. Moreover, for an HH type 1 household, the number of non-agricultural workers linearly increased with increasing number of able-bodied laborers; the relationship $y=0.447 x+0.477$ well fits the data, with $R^{2}=0.94$ (Table 7). This finding suggests that the number of laborers in a household has a significant effect on the household's decision on whether to turn to non-agricultural sectors and the rising non-agricultural employment can decrease the dependence of peasant households on

Table 7 Labor resource allocation among different family types (person/household)

\begin{tabular}{cccccccc}
\hline Family type & $\begin{array}{c}\text { Household's } \\
\text { labor (person) }\end{array}$ & $\begin{array}{c}\text { Average peo- } \\
\text { ple of every } \\
\text { household* }\end{array}$ & $\begin{array}{c}\text { Migrant } \\
\text { workers* }\end{array}$ & $\begin{array}{c}\text { Non-working } \\
\text { people* }\end{array}$ & $\begin{array}{c}\text { Agricultural } \\
\text { workers* }\end{array}$ & $\begin{array}{c}\text { Main migrant } \\
\text { with agricul- } \\
\text { tural workers* }\end{array}$ & $\begin{array}{c}\text { Main agricul- } \\
\text { tural with mi- } \\
\text { grant workers* }\end{array}$ \\
\hline \multirow{2}{*}{ HH type 1 } & 1 & 2.95 & 0.61 & 0.48 & 1.55 & 0.29 & 0.01 \\
& 2 & 4.66 & 0.97 & 1.57 & 1.65 & 0.40 & 0.06 \\
& 4 & 4.65 & 1.10 & 1.47 & 1.56 & 0.48 & 0.04 \\
\hline HH type 2 & 1 & 5.52 & 2.01 & 1.49 & 1.48 & 0.52 & 0.01 \\
\hline HH type 3 & 2 & 6.35 & 2.06 & 2.00 & 1.76 & 0.53 & - \\
\hline Mean value & - & 1.73 & 0.03 & 0.16 & 1.35 & 0.14 & 0.05 \\
\hline
\end{tabular}

\footnotetext{
*Note: Their values are per household, and their units are person per household.
} 
farmland and thereby propel the livelihood shifts.

(2) Non-agricultural sources of livelihood boosted the livelihood shifts

Non-agricultural sources accounted for a significant share of household income/livelihood. The annual per capita income in the study areas was 8677.01 yuan, with $75.61 \%$ coming from non-agricultural activities, and $16.49 \%$ from agriculture, and $7.89 \%$ from assistance such as government subsidies. This demonstrates that non-agricultural activities have dominated the livelihoods of the households (Table 8). The high proportion of non-agricultural sources of income/livelihood is the product of rural economic transformation, outflow of labor, and livelihood diversification and it will further promote the livelihood transition towards non-agricultural work.

Table 8 Income characteristics of different family types (yuan/person)

\begin{tabular}{lcccccc}
\hline Family type $\begin{array}{c}\text { Household's labor } \\
\text { (person) }\end{array}$ & $\begin{array}{l}\text { Off-farm } \\
\text { income* }\end{array}$ & Planting income* & $\begin{array}{c}\text { Breeding } \\
\text { income* }\end{array}$ & $\begin{array}{c}\text { Subsidized } \\
\text { income* }\end{array}$ & Total income* \\
\hline \multirow{2}{*}{ HH type 1 } & 1 & 6335.43 & 244.25 & 921.22 & 1248.00 & 8748.90 \\
& 2 & 6565.66 & 579.68 & 700.35 & 681.03 & 8526.73 \\
& 4 & 7167.32 & 667.82 & 1246.90 & 438.14 & 9520.18 \\
& 5 & 8242.03 & 638.33 & 436.72 & 402.26 & 9719.34 \\
HH type 2 & 1 & 9952.04 & 669.19 & 655.09 & 255.39 & 11531.71 \\
\hline HH type 3 & 2 & 1098.44 & 360.31 & 928.78 & 1501.07 & 3888.60 \\
\hline Mean value & - & 1347.46 & 348.56 & 1674.15 & 1547.25 & 4917.42 \\
\hline
\end{tabular}

*Note: Their values are per capita, and their units are yuan per capita.

The proportion of non-agricultural income varied between household types. As Figure 7 shows, HH type 1 households exhibited the highest proportion of non-agricultural income at $77.94 \%$, compared to $\mathrm{HH}$ type 2 households' $27.66 \%$ and $\mathrm{HH}$ type 3 households' $15.57 \%$. Agricultural income was an important source of income for $\mathrm{HH}$ types 2 and 3 households: its average share in a household's total income was 38.74\% among HH type 2 household and $31.65 \%$ among HH type 3 households. Besides, assistance such as that provided by the gov-

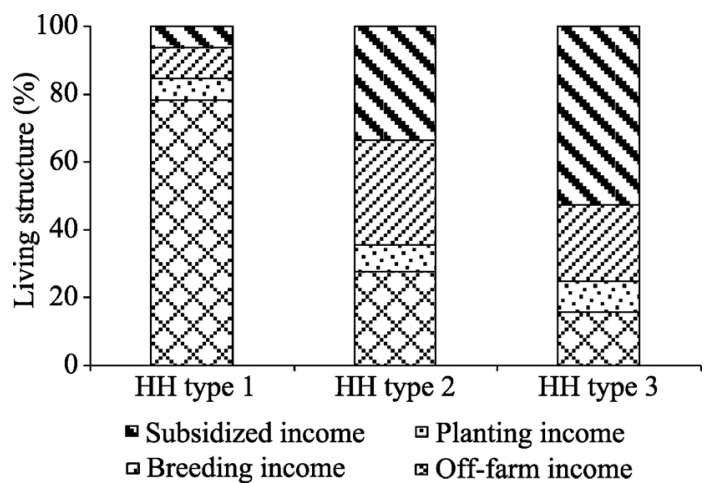

Figure 7 Source structure of different farmer livelihood types ernment, relatives and friends was also an important source of income for $\mathrm{HH}$ types 2 and 3 households. In particular, $\mathrm{HH}$ type 3 households were very dependent on assistance, which made up $52.78 \%$ of their family income. The proportion of agricultural income in household income was below $40 \%$ among the three household types, indicating a growing share of non-agricultural sources in household livelihood. This trend can boost the livelihood shifts towards non-agricultural activities.

(3) Weighing of household income/wel- 
fare in various livelihood scenarios stimulated the livelihood shifts

In the course of livelihood change, household income showed an upward trend and varied widely between various household types. Table 9 shows that the annual average household income in LH type 1 was only 9071.32 yuan, much lower than the 46,360.19 yuan in LH type 2 and 49,658.75 yuan in LH type 3. The annual per capita income in LH type 1 was 2,227.53 yuan, compared with 11,384.11 yuan in LH type 2 and 12,194.10 yuan in LH type 3. The potential economic benefits lured the households away from agriculture. Both annual household and per capita incomes grew as the livelihood shifted from agriculture, through sidelines, to non-agricultural work.

Table 9 Farmers income accounting of different leading livelihood types (yuan/year)

\begin{tabular}{|c|c|c|c|c|c|c|}
\hline \multirow{2}{*}{ Farmer livelihood type } & \multicolumn{2}{|c|}{ Type 1} & \multicolumn{2}{|c|}{ Type 2} & \multicolumn{2}{|c|}{ Type 3} \\
\hline & Per household & Per capita & Per household & Per capita & Per household & Per capita \\
\hline LH type 1 & 9650.16 & 2099.66 & 7565.44 & 3865.86 & 4623.30 & 2632.71 \\
\hline LH type 2 & $55,906.36$ & $12,164.00$ & 7565.44 & 3865.86 & 4669.72 & 2659.14 \\
\hline LH type 3 & $58,935.70$ & $12,823.12$ & $13,930.70$ & 7118.44 & 4669.72 & 2659.14 \\
\hline
\end{tabular}

In LH type 1, the household incomes were low and varied slightly between household types. Annual household incomes ranged between 4623.30 and 9650.16 yuan and per capita

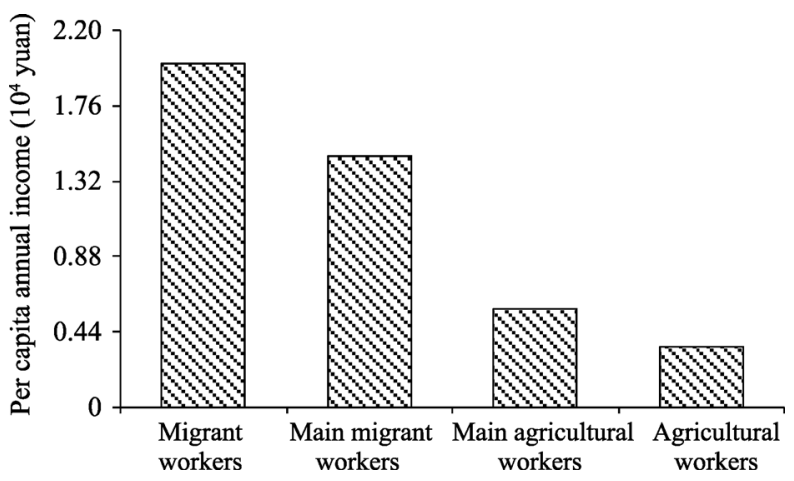

Figure 8 Per capita income of different employment incomes were between 2099.66 and 3865.86 yuan. In LH type 2, household incomes were generally high and varied significantly among household types. Annual household incomes fell within the range of 4669.72 to $55,906.36$ yuan, and per capita income varied between 2659.14 to $12,164.00$ yuan. In LH type 3, the households differed greatly in income, with the widest household income gap at $54,265.98$ yuan and the widest per capita income gap at 10,163.97 yuan. It is noteworthy that the peasants aged over 65 lived in relative poverty. Figure 8 suggests that the wide income gaps were attributed to differences in the nature of various occupations and the households were lured by economic benefits, and led by the market, into non-agricultural sectors to make a living.

Livelihood changes had varied effects on household income growth depending on household types. Table 9 reveals that $\mathrm{HH}$ type 1 households were most influenced by livelihood changes. The household incomes were up more than five-fold maximum; the widest gaps in annual household income and per capita income reached 49,285.54 and 10,723.45 yuan, respectively. HH Type 2 households were less affected by livelihood shifts. The average household income nearly doubled. The widest gaps in household income and per capita income were 6365.26 yuan and 3252.58 yuan, respectively. Average household income grew only about $1 \%$ among $\mathrm{HH}$ type 3 households, indicating that these households benefited the least from livelihood shifts. Figure 9 shows that the variability in the effects of liveli- 


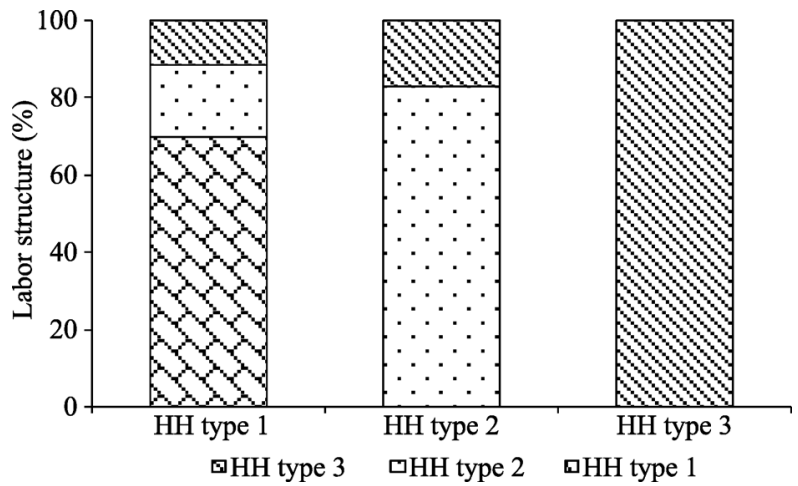

Figure 9 Labor structure of different farmer livelihood types

hood changes was caused by the differences in the number of workers between the three types of households.

The three findings above demonstrate that the manpower differences between households were the endogenous force driving the livelihood shifts while the comparative disadvantage of agriculture was the external driving force behind the changes in livelihood strategies.

The off-farm employment and incomes were important indicators of livelihood shifts, while the weighing of household income/welfare in different scenarios was the major impetus for the livelihood shifts. Furthermore, the rapid modern urbanization and the establishment of an innovation-oriented industrial system can further boost the livelihood shifts, thereby further reducing pollution loads from crop farming. Therefore, in order to substantially reduce pollution produced by crop farming, it is necessary for the authorities to formulate regulatory policies that are favorable to household livelihood shifts towards non-agricultural sectors in mountainous rural areas.

\section{Conclusions}

(1) In the sample areas, part of the farmland was cultivated by contracted families, while the rest was transferred or left uncultivated. The households with semi-able-bodied laborers showed the largest land area under cultivation per capita, at $11.02 \times 10^{-2} \mathrm{hm}^{2}$, compared with $8.66 \times 10^{-2} \mathrm{hm}^{2}$ among the households with no laborer and $6.45 \times 10^{-2} \mathrm{hm}^{2}$ among the households with able-bodied laborers. The highest pollution load from crop farming per unit land area occurred in the households with semi-able-bodied laborers, while the lowest load was observed in the households with no laborer. Among the households with able-bodied laborers, the pollution load from crop farming increased and then decreased with increasing laborer number.

(2) Overall, the total pollution load from crop farming decreased with the livelihood shifts, with the maximum rate of pollution load reduction reaching $72.01 \%$. The reduction in TN was more remarkable than TP reduction. The pollution load from crop farming peaked in the scenario where the household livelihood was dominated by agriculture. In the scenario where the household livelihood was dominated by sidelines, the rates of reduction in pollution load from crop farming ranged from $19.61 \%$ to $29.85 \%$, compared with $35.20 \%$ to $72.01 \%$ in the scenario where the livelihood was dominated by non-agricultural activities. The reduction in pollution load from farming by the households with no laborer was most sensitive to the livelihood shift from agriculture to sidelines and that by the households with semi-able-bodied laborers were most sensitive to the shift from sidelines to non-agricultural activities.

(3) The high off-farm employment and high proportion of non-agricultural income pro- 
pelled the shifts of dominant livelihoods towards non-agricultural activities. Potential weighing of household income/welfare in the course of livelihood shifts stimulated the households to pursue livelihood strategies that were dependent on non-agricultural activities. The types of households were ranked in descending order of sensitivity to livelihood shifts as follows: households with able-bodied laborers, households with semi-able-bodied laborers, and households with no laborer. Additionally, the rapid modern urbanization and the establishment of an innovation-oriented industrial system can further boost the livelihood shifts, thereby further reducing pollution loads from crop farming. Therefore, in order to substantially reduce pollution produced by crop farming, it is necessary for the authorities to formulate regulatory policies that are favorable to household livelihood shifts towards non-agricultural sectors in mountainous rural areas.

\section{References}

Beven K, Kirkby M J, 1979. A physically based, variable contributing area model of basin hydrology. Hydrological Science Bulletin, 24(1): 43-69.

Chen Yucheng, Yang Zhimin, Chen Qinghua et al., 2008. Source apportionment of agricultural non-point source pollution in Chongqing based on pressure-response system. Scientia Agricultura Sinica, 41(8): 2362-2369. (in Chinese)

Feng Xiaojie, Wei Chaofu, Xie Deti et al., 2005. Effects of farm households' management behavior upon non-point pollution of agriculture and model analysis. Chinese Agricultural Science Bulletin, 21(12): 354-358. (in Chinese)

Ganesh C B, John F N, David C R, 2012. Energy savings by adopting precision agriculture in rural USA. Energy, Sustainability and Society, 22(2): 1-5.

Gong Qianwen, Zhang Junbiao, Li Jin, 2008. Impact factor of fertilizer inputs decision based on analysis of the survey data in Hubei Province. Agricultural Economic Question, (10): 65-70. (in Chinese)

Hou Jundong, Lv Jun, Yin Weifeng, 2012. Effects of farmer households' production and operation behaviors on rural eco-environment. China Population Resources and Environment, 22(3): 30-35. (in Chinese)

Li Bin, Ma Jiujie, 2014. The study on impact of labor force transfer on innovation in agricultural production and operation organization innovation and impact of this innovation on change of urban-rural income gap. China Soft Science Magazine, (7): 60-76. (in Chinese)

Li Xiufen, Zhu Jinzhao, Gu Xiaojun et al., 2010. Current situation and control of agricultural non-point source pollution. China Population Resources and Environment, 20(4): 81-84. (in Chinese)

Liang Liutao, Qu Futian, Feng Shuyi, 2010. Study on eco-environmental problems and management system innovation in the process of rural development. Soft Science, 24(8): 53-57. (in Chinese)

Liu Yansui, 2007. Rural transformation development and new countryside construction in eastern coastal area of China. Acta Geographica Sinica, 62(6): 563-570. (in Chinese)

Long Dongping, Li Tongsheng, Miao Yuanyuan et al., 2014. Spatio-temporal characteristics and impacting factors of non-agriculturalization of China's rural population. Progress in Geography, 33(4): 517-530. (in Chinese)

Long Tianyu, Cao Huailiang, An Qiang et al., 2013. Spatial distribution of transfer pollution absorbed phosphorus load in slope farmland of purple soil in Three Gorges Reservoir Region. Transactions of the Chinese Society of Agricultural Engineering (Transactions of the CSAE), 29(4): 157-164. (in Chinese)

Luo Xiaojuan, Feng Shuyi, Reidsma Pytrik et al., 2013. Simulation of agricultural and environmental policy response based on the farmer's bio-economic model: A case study of Taihu River Basin. Chinese Rural Economy, (11): 74-87. (in Chinese)

Ouyang Jinliang, Song Chunmei, Yu Zhenrong et al., 2004. The farm household's choice of land use type and its effectiveness on land quality and environment in Huang-Huai-Hai Plain. Journal of Natural Resources, 19(1): 
1-11. (in Chinese)

Rozelle S, Boisvert R N, 1995. Control in a dynamic village economy: The reforms and unbalanced development in China's rural economy. Journal of Development Economics, 46(2): 233-252.

Sharma D K, Ghosh D, Alade J A, 2006. A fuzzy goal programming approach for regional rural development planning. Applied Mathematics and Computation, 176(1): 141-149.

Shui Shangnan, 2013. Options for agricultural business model: Capital farm or co-operative. Issues in Agricultural Economy, (8): 32-36. (in Chinese)

Walford N, 2005. Multifunctional agriculture a new paradigm for European agriculture and rural development. Land Use Policy, 22(4): 387.

Xu Ping, Zhang Zhengbin, Wang Jianzhong et al., 2004. Development directions of Chinese agriculture in future. World Sci-tech $R \&$ \& , 26(6): 65-68. (in Chinese)

Yang Linzhang, Shi Weiming, Xue Lihong et al., 2013. Reduce-retain-reuse-restore technology for the controlling the agricultural non-point source pollution in countryside in China: General Countermeasures and Technologies. Journal of Agro-Environment Science, 32(1): 1-8. (in Chinese)

Zhang Wuwei, Zhang Fuming, Yang Xuecheng, 2009. The relationship between the transfer of surplus rural labor force and its land disposal: An analysis based on the survey data of 2421 agricultural transfer labor force in Shandong Province. Chinese Rural Economy, (3): 85-90. (in Chinese)

Zhang Yan, Gao Xiang, Zhang Hong, 2012. Association study between water quality of Chaohu lake and resources input in agriculture of basin. Environmental Sciences, 33(9): 3009-3013. (in Chinese)

Zhao Chunyu, Su Qin, Fang Jueshu, 2013. The research system and methods of the rural labor's environment cognition in the employment transference's process. Geographical Research, 32(5): 891-901. (in Chinese)

Zhao Xueyan, 2012. Environmental perception of farmers of different livelihood strategies: A case of Gannan Plateau. Acta Ecologica Sinica, 32(21): 6776-6787. (in Chinese)

Zhong Jianbing, Shao Jing'an, Xie Deti et al., 2014. Evaluation and changing characteristics of fertilizer input in different agricultural systems in the Three Gorges Reservoir Area. Chinese Journal of Eco-Agriculture, 22(11): 1372-1378. (in Chinese)

Zhong Jianbing, Shao Jing'an, Yang Yuzhu, 2015. Spatial distribution characteristics of pollution load of crop farming in the Three Gorges Reservoir Area (Chongqing). Acta Scientiae Circumstantiae, 35(7): 2150-2159. (in Chinese) 